\title{
The Influence of Precursory Plant on Winter Wheat Production from Long-Term Experiences
}

\author{
Valeria DEAC ${ }^{1,2}$, Ioan ROTAR ${ }^{2 *}$, Roxana VIDICAN², Mircea IGNEA ${ }^{1}$, Anamaria MĂLINAȘ ${ }^{2}$ \\ ${ }^{1}$ Agrotechnical Department, Agricultural Research- Development Station Turda \\ ${ }^{2}$ Faculty of Agriculture, University of Agricultural Science and Veterinary Medicine Cluj - Napoca, \\ Manastur Str., No. 3-5, Cluj-Napoca, Romania; \\ * corresponding author: rotarioan52@yahoo.fr
}

Bulletin USAMV series Agriculture 72(1)/2015

Print ISSN 1843-5246; Electronic ISSN 1843-5386

DOI 10.15835/buasvmcn-agr: 11161

\begin{abstract}
Winter wheat is strongly influenced by the precursory plant. The rotational experiences established in the experimental fields of ARDS Turda, started in 1967, and are installed as follows: winter wheat after soybean, soybean, potatoes, winter wheat after maize and maize. In this paper we studied the influence of precursory plant, as a factor which influences winter wheat productivity. Our results showed that the precursory plant has a distinguish effect on winter wheat productivity. We registered yields higher with $273 \mathrm{~kg} / \mathrm{ha}$ when winter wheat was cultivated after soybean compared to the yields achieved when winter wheat was cultivated after maize (control variant). Indubitable fertilization had the greatest contribution to these results but the effect of precursory plant is also significant.
\end{abstract}

Keyworlds: long-term experiences, nitrogen doses, phosphorus doses, precursory plant, winter wheat.

\section{INTRODUCTION}

Long-term experiences with mineral fertilization have the role to evaluate and to study what happens to soil from different areas of the country. Besides the genetic factors, technological factors and first of all the mineral fertilization significantly influence the wheat qualitative indices (Ştefănescu and Tianu, 2001). Th e use of plow-down cover crops, specifically legume green manures, to improve soil fertility is a wellestablished concept (Biederbeck et al., 1998, quoted by Miller et al., 2015). Winter wheat is a plant which reacts strongly to precursory plant. For achieving higher production in wheat yield is necessary to include it into a rational crop system. This is a condition which is recommended for fertile and well maintained soil and is a mandatory measure for poorly fertile soils, infested with weeds, pests and diseases. The rotation system is an option used for diseases, weeds and pests control and prevention (Munteanu et al., 2008).

Based on experimental results, Salontai (1982) made a classification of precursory plant for winter wheat for the condition specific to our geographic area. He concluded that within the most recommended precursory plant for winter wheat are: grain legume (pea, been, soybean, fava bean), rape, red clover, early potatoes; the good precursory plant are: sugar beet, tobacco, maize, sunflower and mediocre precursory plant are: wheat, barley, oat, rye, Sudan grass.

At ARDS Turda, since 1967 and currently, is ongoing a long term experiment with mineral fertilizer of NP type. The experiments are located within a five-year rotation: wheat after soybeanssoybean-potato-wheat after maize-corn. We observed that two of the plants after which winter 
wheat is cultivated, are included in the categories of very good and good precursory plant (after Salontai classification, 1982).

Soybean crop has a positive influence on soil, since soybean is a breeder plant which leaves amounts of nitrogen up to $80-120 \mathrm{~kg} / \mathrm{ha}$. When maize is the precursory plant, is necessary to perform soil tillage in a very short time after harvesting of maize for seeding in the optimum period of time. The cultivation of wheat after corn is interrupted if the Fusarium spp. attack has been reported, which is a commune pest for both cultures.

A research conducted in South America on stress caused by water in conditions of nitrogen fertilization, concluded that soybean turns from a plant up to very good or good in one modest or poor (Maria Ramos et al., 2003, Thomas et al., 2004, quoted by Berca, 2011).

We are aware that corn is not as good as soybean as precursory plant for wheat, but under specific conditions and in accordance with our country's cereal crop rotation, one can get use with corn as precursory plant for wheat. I n this context the present paper aims to follow the contribution of precursory plant on winter wheat productivity in an experimental system with fertilizer. The experimental plots were fertilized as follows: wheat after soybean, fertilized with $\mathrm{P}_{0}, \mathrm{P}_{40}$, $\mathrm{P}_{80}, \mathrm{P}_{120}, \mathrm{P}_{160}$, applied in autumn before ploughing, $\mathrm{N}_{0}, \mathrm{~N}_{40}, \mathrm{~N}_{120}$, applied half quantity in autumn and half in spring in growing season. The same doses and on the same way of application were made also on wheat after corn.

\section{MATERIAL AND METHODS}

The experiment was conducted on ARDS TURDA in the field of long-term experiences. These experiments were installed after randomized blocks method, with 25 variants in 6 replication.

The experimental factors considered and their graduations are as follows:

1. Precursory plant: $A$ : with 2 graduations: $A 1=$ maize and $A 2=$ soybean

2. Experimental years: with 3 graduations: $\mathrm{B} 1=$ 2012; B2=2013; B3=2014.

3. Doses of phosphorus: with 5 graduations: $\mathrm{C} 1=$ $\mathrm{P}_{0} ; \mathrm{C} 2=\mathrm{P}_{40} ; \mathrm{C} 3=\mathrm{P}_{80} ; \mathrm{C} 4=\mathrm{P}_{120} ; \mathrm{C} 5=\mathrm{P}_{160}$.

4. Doses of nitrogen: with 3 graduations: $\mathrm{D} 1=\mathrm{N}_{0}$; $\mathrm{D} 2=\mathrm{N}_{40} ; \mathrm{D} 3=\mathrm{N}_{120^{*}}$.

The winter wheat cultivar used in this experiment is: DUMBRAVA. Fertilizer on wheat after soybean and wheat after maize was applied in the following doses:

Tab.1. Soil from ARDS TURDA characteristics (Agrotechnics, 2009)

\begin{tabular}{|c|c|c|c|c|c|c|c|c|c|c|c|c|c|c|c|c|}
\hline \multirow{2}{*}{$=\frac{\vec{D}}{0}$} & \multirow{2}{*}{$\begin{array}{l}\text { Sample } \\
\text { number }\end{array}$} & \multirow{2}{*}{$\begin{array}{c}\text { Depth } \\
\text { of the } \\
\text { sample }\end{array}$} & \multicolumn{2}{|c|}{$\mathrm{PH}$} & \multicolumn{2}{|c|}{$\begin{array}{c}\text { mobile P } \\
(\mathrm{ppm})\end{array}$} & \multicolumn{2}{|c|}{$\begin{array}{c}\text { mobile K } \\
(\mathrm{ppm})\end{array}$} & \multicolumn{2}{|c|}{ Humus } & \multicolumn{5}{|c|}{ Granulometric analyses } & \multirow{2}{*}{$\begin{array}{c}\begin{array}{c}\text { Soil } \\
\text { structure }\end{array} \\
\text { Clay }\end{array}$} \\
\hline & & & Val & Exp & Val. & Expl. & Val. & Expl. & Val. & Expl & $\begin{array}{c}\text { Tought } \\
\text { sand }\end{array}$ & $\begin{array}{l}\text { Fine } \\
\text { sand }\end{array}$ & $\begin{array}{c}\text { Dust } \\
\text { I }\end{array}$ & $\begin{array}{c}\text { Dust } \\
\text { II }\end{array}$ & & \\
\hline \multirow{2}{*}{ 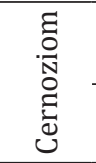 } & 1 & $0-20$ & 7.03 & neutr & 63.0 & good & 380.0 & $\begin{array}{l}\text { very } \\
\text { good }\end{array}$ & 3.87 & iddle & 0.10 & 23.10 & 11.5 & 21.20 & 44.0 & Clay-loa \\
\hline & 2 & $20-40$ & 7.05 & neutr & 36.0 & middle & 334.0 & $\begin{array}{l}\text { very } \\
\text { good }\end{array}$ & 3.2 & hiddle & 0.15 & 21.55 & 10.8 & 22.60 & 44.9 & Clay-loar \\
\hline
\end{tabular}

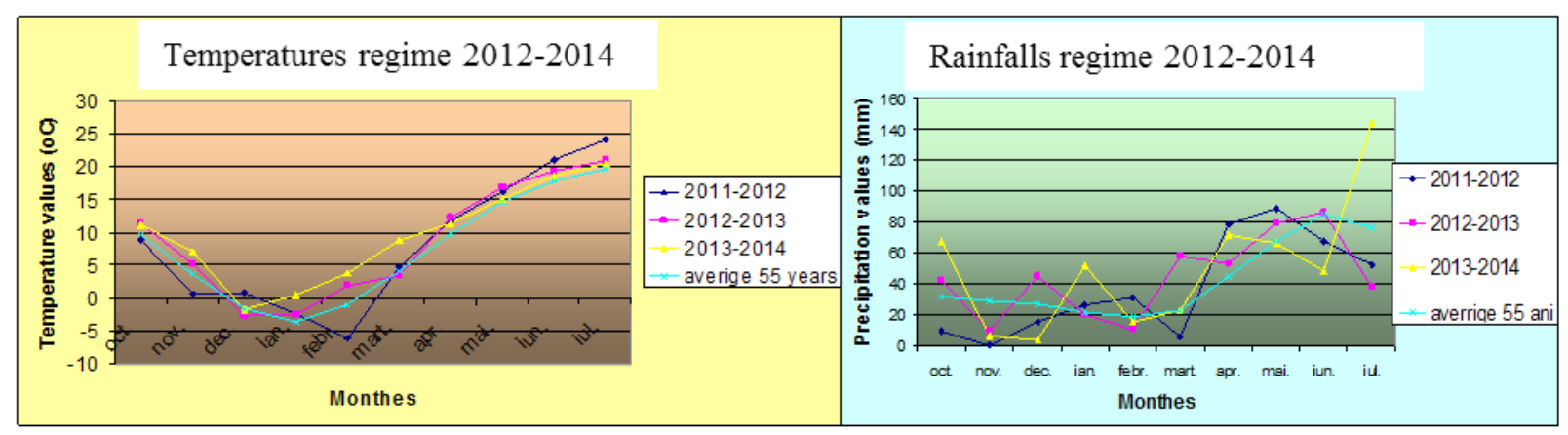

Fig. 1. Temperatures regime in experimental years
Fig. 2. Rainfalls regime in experimental years 
- Doses of phosphorus: $\mathrm{P}_{0}, \mathrm{P}_{40}, \mathrm{P}_{80}, \mathrm{P}_{120}, \mathrm{P}_{160}$, in autumn under plowing;

- Doses of nitrogen: $\mathrm{N}_{0}, \mathrm{~N}_{40}, \mathrm{~N}_{120}$, half doses applied in autumn and the rest in spring, on growing period.

Soil chemical analysis presented in Tab. 1 shows that the type of soil specific to ARDS Turda is cernoziom with neutral PH and medium values in humus, aspects which suggest that a supply with mobile $\mathrm{P}$ and $\mathrm{K}$ is welcome in this situation.

The climatic conditions registered in the 3 experimental years studied were different along winter wheat's vegetation period (Fig. 1, Fig. 2). The year 2012 was hot and dry generally and after the winter of 2011-2012 which was hot and with rainfalls in February, wheat grew in March. A warm spring has followed, with 2 very rainy months: April and May. This two months were decisive for wheat production. Autumn of 2012 was hot and dry, drought was balanced by the rains fallen in winter. The spring of 2013 year was well balanced, achieving equilibrium between the dry and the rainy months. The autumn of 2013 year was normally both from temperatures and rains point of view. The spring of 2014 year was rainy and hot, favoring the achievement of very good production.

\section{RESULTS AND DISCUSSIONS}

The results showed that the experimental years had a significant influence on winter wheat productivity and that the climatic conditions favored the assimilation of nutrients from soil and from atmosphere. If in the normal year 2013, the production of wheat after maize variant decreased as a result of rains which have fallen in the vegetation period (reaching a production lower with $151 \mathrm{~kg} / \mathrm{ha}$ compared to 2012), in 2014 year (hot and rainy), a difference of $642 \mathrm{~kg} / \mathrm{ha}$ in yields showed a significant contribution to the registered production (Tab. 2). In which concerns wheat after soybean as precursory plant the reaction is the same along the 3 experimental years. If in 2013 winter wheat productivity met a decrease with $143 \mathrm{~kg} / \mathrm{ha}$ compared with the yields registered in 2012, in 2014 we registered productions higher with $1494 \mathrm{~kg} / \mathrm{ha}$ than those registered in 2012 .

Analyzing the effect of phosphorus fertilization on winter wheat productivity we observed that phosphorus doses applied in autumn gave the highest wheat yield when soybean was precursory plant on all fertilization graduations (Tab. 3). The highest difference of $345 \mathrm{~kg} / \mathrm{ha}$ was observed when $\mathrm{P}_{160}$ were applied (on wheat after maize we registered $4934 \mathrm{~kg} / \mathrm{ha}$ compared with $5279 \mathrm{~kg} / \mathrm{ha}$ registered on wheat after soybean).

In which concerns the effect of nitrogen doses on winter wheat productivity a very significant influence is observed (Tab. 4). Analyzing the influence of interaction between precursory plant and nitrogen doses on winter wheat production we observed that the highest productions were registered on wheat after soybean on all fertilization graduations. For example on variant fertilized with $\mathrm{N}_{40}$ we registered yields higher with $428 \mathrm{~kg} / \mathrm{ha}$ when soybean was precursory plant compared to the variant where maize was the precursory plant, difference very significant from statistical point of view. Our results showed that the optimum dose is $\mathrm{N}_{40}$, in wheat after soybean system.

Tab. 2. The influence of interaction between experimental years and precursory plant on winter wheat production (ARDS Turda, 2012 - 2014)

\begin{tabular}{|c|c|c|c|c|c|}
\hline Precursory plant & $\begin{array}{c}\text { Experimental } \\
\text { year }\end{array}$ & $\begin{array}{c}\text { Production } \\
\text { (kg/ha) }\end{array}$ & $\begin{array}{c}\text { Production } \\
(\%)\end{array}$ & $\begin{array}{c}\text { Differences } \\
\text { (kg/ha) }\end{array}$ & Signification \\
\hline \multirow{3}{*}{ Wheat after maize } & 2012 & 4572 & 100.0 & 0 & wt. \\
\hline & 2013 & 4420 & 96.7 & -151 & - \\
\hline & 2014 & 5214 & 114.0 & 642 & $* * *$ \\
\hline \multirow{3}{*}{ Wheat after soybean } & 2012 & 4559 & 100.0 & 0 & wt. \\
\hline & 2013 & 4416 & 96.9 & -143 & - \\
\hline & 2014 & 6052 & 132.8 & 1494 & $* * *$ \\
\hline
\end{tabular}


Analyzing the influence of interaction between phosphorus doses and nitrogen doses on winter wheat production we observed that the highest productions were registered when doses of both 2 nutrients were high (Tab. 5). The highest increases of production were obtained to $\mathrm{N}_{40} \mathrm{P}_{160}$ with a difference of $745 \mathrm{~kg} / \mathrm{ha}$, compared to witness. When $\mathrm{N}_{120} \mathrm{P}_{160}$ were applied we registered an increase, in wheat production with $563 \mathrm{~kg} / \mathrm{ha}$ which is distinct significant. The results obtained allow us to recommend the fertilization with $\mathrm{N}_{40} \mathrm{P}_{120}$.

\section{CONCLUSION}

The results registered among the 3 experimental years studied, showed distinctly significant influence of precursory plant on wheat productivity. The highest yield was obtained in the wheat after soybean crop system.

Analyzing the interaction between experimental years and precursory plant we observed that on wheat grown after soybean the yields were higher with $1494 \mathrm{~kg} / \mathrm{ha}$ compared to those registered on wheat grown after maize in the year 2014.

Tab. 3. The influence of interaction between precursory plant and phosphorus doses on winter wheat production (ARDS Turda, 2012 - 2014)

\begin{tabular}{cccccc}
\hline Precursory plant & Doses of phosphorus & $\begin{array}{c}\text { Production } \\
(\mathrm{kg} / \mathrm{ha})\end{array}$ & $\begin{array}{c}\text { Production } \\
(\%)\end{array}$ & $\begin{array}{c}\text { Differences } \\
(\mathrm{kg} / \mathrm{ha})\end{array}$ & Signification \\
\hline Wheat after maize & $\mathrm{P}_{0}$ & 4478 & 100.0 & 0 & wt. \\
\hline Wheat after soybean & $\mathrm{P}_{0}$ & 4768 & 106.5 & 290 & $* *$ \\
\hline Wheat after maize & $\mathrm{P}_{40}$ & 4682 & 100.0 & 0 & $\mathrm{wt}$ \\
\hline Wheat after soybean & $\mathrm{P}_{40}$ & 4916 & 105.0 & 234 & $*$ \\
\hline Wheat after maize & $\mathrm{P}_{80}$ & 4752 & 100.0 & 0 & $\mathrm{wt}$ \\
\hline Wheat after soybean & $\mathrm{P}_{80}$ & 5038 & 106.0 & 287 & $* *$ \\
\hline Wheat after maize & $\mathrm{P}_{120}$ & 4832 & 100.0 & 0 & $\mathrm{wt}$ \\
\hline Wheat after soybean & $\mathrm{P}_{120}$ & 5043 & 104.4 & 211 & $* *$ \\
\hline Wheat after maize & $\mathrm{P}_{160}$ & 4934 & 100.0 & 0 & $\mathrm{wt}$ \\
\hline Wheat after soybean & $\mathrm{P}_{160}$ & 5279 & 107.0 & 345 & $*$ \\
\hline DL5\% 118 DL1\% 182 DL0.1\% 347 & & & &
\end{tabular}

Tab. 4. The influence of interaction between precursory plant and nitrogen doses on winter wheat production (ARDS Turda, 2012 - 2014)

\begin{tabular}{|c|c|c|c|c|c|}
\hline Precursory plant & Doses of nitrogen & $\begin{array}{c}\text { Production } \\
(\mathrm{kg} / \mathrm{ha})\end{array}$ & $\begin{array}{c}\text { Production } \\
(\%)\end{array}$ & $\begin{array}{c}\text { Differences } \\
(\mathrm{kg} / \mathrm{ha})\end{array}$ & Signification \\
\hline Wheat after maize & $\mathrm{N}_{0}$ & 3082 & 100.0 & 0 & wt. \\
\hline Wheat after soybean & $\mathrm{N}_{0}$ & 3970 & 109.3 & 288 & $* *$ \\
\hline Wheat after maize & $\mathrm{N}_{40}$ & 4886 & 100.0 & 0 & wt \\
\hline Wheat after soybean & $\mathrm{N}_{40}$ & 5344 & 108.8 & 428 & $* * *$ \\
\hline Wheat after maize & $\mathrm{N}_{120}$ & 5530 & 100.0 & 0 & wt \\
\hline Wheat after soybean & $\mathrm{N}_{120}$ & 5662 & 102.4 & 132 & $*$ \\
\hline
\end{tabular}


Tab. 5. The influence of interaction between phosphorus doses and nitrogen doses on winter wheat production (ARDS Turda, 2012 - 2014)

\begin{tabular}{|c|c|c|c|c|c|}
\hline $\begin{array}{c}\text { Doses of } \\
\text { phosphorus }\end{array}$ & $\begin{array}{l}\text { Doses of } \\
\text { nitrogen }\end{array}$ & $\begin{array}{c}\text { Production (kg/ } \\
\mathrm{ha}\end{array}$ & $\begin{array}{c}\text { Production } \\
(\%)\end{array}$ & $\begin{array}{c}\text { Differences (kg/ } \\
\text { ha) }\end{array}$ & Signification \\
\hline $\mathrm{P}_{0}$ & $\mathrm{~N}_{0}$ & 3658 & 100.0 & 0 & wt. \\
\hline $\mathrm{P}_{40}$ & $\mathrm{~N}_{0}$ & 3752 & 102.6 & 95 & - \\
\hline $\mathrm{P}_{80}$ & $\mathrm{~N}_{0}$ & 3598 & 98.4 & -60 & - \\
\hline $\mathrm{P}_{120}$ & $\mathrm{~N}_{0}$ & 3702 & 101.2 & 45 & - \\
\hline $\mathrm{P}_{160}$ & $\mathrm{~N}_{0}$ & 3800 & 103.9 & 142 & - \\
\hline $\mathrm{P}_{0}$ & $\mathrm{~N}_{40}$ & 4566 & 100.0 & 0 & wt \\
\hline $\mathrm{P}_{40}$ & $\mathrm{~N}_{40}$ & 5002 & 109.5 & 436 & $* * *$ \\
\hline $\mathrm{P}_{80}$ & $\mathrm{~N}_{40}$ & 5063 & 110.9 & 497 & $* * *$ \\
\hline $\mathrm{P}_{120}$ & $\mathrm{~N}_{40}$ & 5208 & 114.1 & 642 & $* * *$ \\
\hline $\mathrm{P}_{160}$ & $\mathrm{~N}_{40}$ & 5311 & 116.3 & 745 & $* * *$ \\
\hline $\mathrm{P}_{0}$ & $\mathrm{~N}_{120}$ & 5645 & 100.0 & 0 & wt \\
\hline $\mathrm{P}_{40}$ & $\mathrm{~N}_{120}$ & 5644 & 100.0 & -1 & - \\
\hline $\mathrm{P}_{80}$ & $\mathrm{~N}_{120}$ & 6023 & 106.7 & 379 & $* * *$ \\
\hline $\mathrm{P}_{120}$ & $\mathrm{~N}_{120}$ & 5902 & 104.6 & 258 & $* * *$ \\
\hline$\frac{\mathrm{P}_{160}}{149 \mathrm{DL1} \% 198 \mathrm{I}}$ & $\mathrm{N}_{120}$ & 6208 & 110.0 & 563 & $* * *$ \\
\hline
\end{tabular}

The influence of phosphorus fertilization was defined by the yields increases obtained. The highest production registered of $5279 \mathrm{~kg} / \mathrm{ha}$ was achieved on wheat after soybean when $\mathrm{P}_{160}$ were applied yields higher with $345 \mathrm{~kg} /$ ha compared to those registered on wheat after maize on the same fertilization dose. In which concerns the influence of nitrogen fertilization on wheat productivity, the highest yield of $5662 \mathrm{~kg} / \mathrm{ha}$ was registered on wheat after soybean when $\mathrm{N}_{120}$ were applied.

In conclusion our studies highlighted once again, if proof were still needed, that in case of cereal crop rotation it is very useful to introduce a vegetable, because the nitrogen amount remained in soil has a positive effect on wheat crop.

Based on the results obtained we recommend soybean as precursory plant for winter wheat, fertilized with $\mathrm{N}_{40} \mathrm{P}_{120}$, variants where we registered the highest winter wheat yields.

Acknowledgments. This paper was published under the frame of European Social Found, Human Resources Development Operational Programme 2007-2013, project no. POSDRU/159/1.5/S/132765".

\section{REFERENCES}

5. Berca M (2011). Agricultural technology - modern transformation of agriculture. Print house Ceres Bucureşti.

6. Biederbeck VO, Campbell CA, Rasiah V, Zentner RP, Wen $G$ (1998). Soil quality attributes as influenced by annual legumes used as green manure. Soil Biol. Biochem. 30:1177-1185.

7. Gus P, Rusu T, Bogdan I (2004). Cropping, crop rotation and land management. Printhouse Risoprint, Cluj-Napoca.

8. Miller PR, Bekkerman A, Clain AJ, Macdonald HB, Holmes JA, Engel RE (2015). Pea in Rotation with Wheat Reduced Uncertainty of Economic Returns in Southwest Montana. Agron. J. 107:541-550.

9. Muntean LS, Solovăstru C, Morar G, Duda MM, Vârban DI, Muntean S (2011). Planttechnics. Second edition. Printhouse Risoprint, Cluj-Napoca. ISBN 978-973-530506-2.

10. Ramos MLG, Parsons R, Sprent JI, Euan KJ (2003). Effect of water stress on nitrogen fixation and nodule structure of common bean. Pesq. agropec. bras., Brasília 38(3):339347.

11. Stefănescu M, Tianu M (2001). Influence of fertilization on some qualitative indices of wheat yield. INCDA Fundulea $16: 23-36$

12. Thomas SG, Sun TP (2004). Update on gibberellin signaling. A tale of the tall and the short. Plant Physiol. 135:668-676 